outbreaks in the field, their value is much more questionable. The authors doubt whether in a pandemic "subcutaneous inoculation" would show "more than a minimal effect on incidence". They are attracted by the theoretical advantages of attenuating a virus by egg-passage and giving it up the nose by atomizer in the living state. They think that at short notice a bacteriological laboratory could in a week make enough attenuated virus for 100,000 persons. Yet they grant that as yet no attenuated strain has been found with the necessary combination of negligible virulence and good immunizing powers.

Some excess of optimism peeps out every few pages in another connexion: the authors have been so successful in isolating viruses by amniotic inoculation of eggs straight from human material that they regard this method as of universal application. But one must not forget that influenza viruses differ greatly from one outbreak to another, and that workers in Great Britain and the United States have not found this technique very successful in the outbreaks they have studied.

The reviewer felt that the last chapter fell a little flat after the excellent eight chapters which preceded it, raising such hopes of a thrilling dénouement. Perhaps this was unreasonable; it is a lot to ask for a ready-made solution of one of the biggest public health problems of these times.

\section{H. Andrewes.}

\section{THE 'FRIENDLY' ARCTIC}

\section{Ultima Thule}

Further Mysteries of the Arctic. By Vilhjalmur Stefansson. Pp. 256. (London, Toronto, Bombay and Sydney: George G. Harrap and Co., Ltd., 1942.) 10s. 6d. net.

$\mathrm{T}$ HE writer of this book is well known for his long campaign to establish the idea of the 'friendly' Arctic. 'The present volume continues the campaign, although the approach is rather different. The main theme is to prove "the strong hold of classic theory upon the minds of our contemporaries". An appeal is therefore made to history in an attempt to show that Pytheas and Columbus, who, it is argued, knew the facts about Arctic conditions, were better informed than the modern climatologist, who insists that the Arctic is really a cold part of the world.

Such an approach involves much detailed consideration of the exploration of "Ultima Thule", and an impressive body of evidence is produced to prove the thesis. There is some attempt, too, to present both sides of the case. But one can scarcely escape the fact that much of the argument comes very near special pleading. Thus the author quotes from a summary, in the Scottish Geographical Magazine, of the views of Dr. Schott on the height of waves: "he considers waves higher than 60 feet can hardly occur, and that 50 feet must be a very exceptional height", and then comments that "this technical journal, then, feels that 60 feet as the maximum height of a wave is probably an underestimate". This argument, in turn, is held to justify the statements of Las Casas and of Ferdinand Columbus that waves of 54 feet "do not show an exaggerated height let alone an absurd one".

The historical method of approach also compels the author to read into early maps his own interpretations. Thus, the famous world map of La Cosa, some of whose knowledge was gained from his intimate association with Columbus, proves really nothing about the Arctic, unless it is that the state of knowledge in 1500 was very confused. This confusion remained long after La Cosa. A better knowledge of the maps of the 'Age of Discovery' would have warned the author that these maps frequently combine speculation and knowledge.

Finally, Mr. Stefansson makes great play with high temperatures recorded from time to time in the Arctic, and proceeds to make a violent attack on orthodox climatologists including R. de C. Ward, whose reputation is established. It cannot be said that these methods make the case any better; on the contrary, they introduce a spirit which is unnecessary in sound argument. It is true, as the reader is told on the dust cover, that Mr. Stefansson "comes to many startling conclusions". It is also true that while the conclusions may startle, they do not always convince the reader. J. N. L. BAKER.

\section{PARASITOLOGY}

\section{Introduction to Parasitology}

By Prof. A. S. Pearse. Pp. ix +357. (Springfield, Ill., and Baltimore, Md.: Charles C. Thomas; London: Baillière, Tindall and Cox, 1942.) 3.75 dollars.

7 HIS volume is intended by its author to serve as a guide and companion to a term's course of theoretical and practical instruction in parasitology for biology students. The subject is completely covered from Protozoa to Chordata. The descriptive matter is sometimes very scrappy and occasionally capable of misconstruction, but actual biological details are accurate.

The parasites of man generally receive adequate treatment, but Sarcoptes Scabiei is dismissed very shortly and without mention of recent work on its life history. Malaria and hookworm disease are given due prominence in separate chapters. The medical treatment required in human parasitic diseases is included, and on the whole, the facts given are accurate though sometimes outmoded. The surgical procedure advised in the treatment of amœbic dysentery would be unintelligible to a non-medical reader, and has apparently been imperfectly understood by the author. Notes on epidemiology are included where necessary.

The diseases of domestic animals, game and fish are discussed more fully than parasite infections of animals which have no effects on human economy.

An, excellent series of line drawings illustrates nearly every subject, and life-cycles of parasites in a host or hosts are clearly and simply portrayed. An introduction explains the terms used and gives a good description of the modes of life of parasites.

It is often difficult to follow the subject matter in the main sections, for the planning and lay-out of the book make it seem compressed. Practical and field work are described.

The final chapter is frankly astonishing. Though possibly suitable in a course of instruction for travelling salesmen, its phraseology is oddly out of place in a scientific work. As a work of reference for biology students and for amateur biologists, the book can be recommended. Better planning and more coherent reading matter could have opened this fascinating subject to a much wider field of readers. 